ŁUKASZ GEMZIAK

Instytut Politologii UMK

\title{
Obwód Kaliningradzki - rosyjska enklawa wewnątrz Unii Europejskiej
}

W

raz z rozszerzeniem Unii Europejskiej, dokonanym w maju 2004 roku, zmianie uległy pewne relacje polityczne na naszym kontynencie. Powiększenie Unii o dziesięć krajów, spośród których większość leżała kiedyś w radzieckiej sferze wpływów bądź wprost wchodziła w skład ZSRR, musiało wpłynąć na wzajemne unijno-rosyjskie stosunki. Również relacje na poziomie międzypaństwowym nie pozostały bez zmian.

W tym kontekście duże znaczenie zostało nadane Obwodowi Kaliningradzkiemu, który za sprawą rozszerzenia z 2004 roku stał się rosyjską enklawą wewnątrz Unii Europejskiej. Federacja Rosyjska (FR) niejednokrotnie podnosiła tę kwestię w rozmowach unijno-rosyjskich. Zagadnienie Obwodu Kaliningradzkiego nieobce było również Polsce i Litwie - sąsiadom Kaliningradu - które wkrótce miały się stać członkami Unii.

Wśród wielu ekspertów zajmujących się problematyką relacji pomiędzy UE a FR funkcjonuje pogląd, iż Obwód Kaliningradzki jest swego rodzaju papierkiem lakmusowym wzajemnych powiązań unijno-rosyjskich ${ }^{1}$. Stosunek Unii Europejskiej do „najbardziej zachodniego” spośród rosyjskich re-

A. Stępień-Kuczyńska, Rosja: ku Europie. Z problematyki stosunków rosyjsko-unijnych, Toruń 2007, s. 214; O. Szura, Status enklawy kaliningradzkiej w kontekście przyjęcia Polski i Litwy do Unii Europejskiej, w: Dylematy integracyjne Polski. Wybrane problemy, M. Stolarczyk (red.), Katowice 2003, s. 152. 
gionów miałby więc być odzwierciedleniem relacji pomiędzy Unią Europejską a Federacją Rosyjską. Analogicznie, określone podejście Moskwy do Kaliningradu świadczyłoby o znaczeniu kierunku europejskiego dla Rosjan.

Rola, jaką odgrywa Obwód Kaliningradzki w stosunkach unijnorosyjskich, skłania do refleksji nad miejscem tego regionu w rosyjskiej oraz unijnej polityce. Można zaryzykować stwierdzenie, że rosyjska enklawa wewnątrz UE jest obszarem, gdzie obydwaj aktorzy sceny międzynarodowej wypróbowują pewne rozwiązania. Rozwiązania te, o ile okażą się skuteczne i przydatne, mogą być wykorzystywane na szerszą skalę. W przeciwnym razie mamy do czynienia z nieudanymi eksperymentami i zbieraniem doświadczeń. Uprawnione wydaje się również określenie Obwodu Kaliningradzkiego mianem barometru zmian w relacjach unijno-rosyjskich.

Przedstawienie znaczenia Kaliningradu dla stosunków pomiędzy Moskwą a Brukselą obejmować będzie okres ostatnich kilkunastu lat. Wraz $\mathrm{z}$ rozpadem ZSRR Obwód Kaliningradzki stał się rosyjską enklawą. W tym wypadku nawiązywanie kontaktów z sąsiadami stało się nieuniknione. Z drugiej strony EWG, a później Unia Europejska zainteresowały się „oswajaniem" nowo powstałej sytuacji. Sprawa okazała się jednak na tyle złożona, że do dziś stanowi dla Brukseli ważny element rozmów z Moskwą. W tym kontekście szczególnie ważną datą jest rok 2004, kiedy to zostało dokonane rozszerzenie Unii Europejskiej o dziesięciu nowych członków. Fakt ten wywarł znaczący wpływ na relacje unijno-rosyjskie. Zmieniła się również sytuacja samego Obwodu Kaliningradzkiego, który od tamtego czasu nazywany jest rosyjską enklawą wewnątrz Unii Europejskiej. Ze zrozumiałych względów okres ten podlegał będzie szczególnej analizie, niejako wymuszając pytanie o bilans rozszerzenia z 2004 roku z punktu widzenia Obwodu Kaliningradzkiego. Odpowiedzi na to pytanie należy doszukiwać się w wydarzeniach ostatnich kilku lat, kiedy to rozszerzona Unia Europejska w składzie 25, a nieco później 27 członków, zmuszona była niejako na nowo ułożyć swoje relacje z Federacją Rosyjską.

W burzliwym okresie XX wieku teren dzisiejszego Obwodu Kaliningradzkiego trzykrotnie zmieniał swój status. Najpierw w latach 1919-1939, wchodząc w skład Prus Wschodnich, stanowił część niemieckiego terytorium. Po II wojnie światowej stał się zamkniętą radziecką strefą wojskową, a w roku 1991 uzyskał status rosyjskiego obszaru odizolowanego od zwartego terytorium Rosji. Wraz z rozszerzeniem Unii Europejskiej o Polskę i Litwę w 2004 roku Kaliningrad stał się rosyjską enklawą wewnątrz Unii Europej- 
skiej². Jednak najważniejsze wydarzenia dla przyszłości dzisiejszego Obwodu rozegrały się zaraz po II wojnie światowej.

Dekretem Prezydium Rady Najwyższej ZSRR z dnia 7 kwietnia 1946 r. na terytorium północnej części Prus Wschodnich utworzono Obwód Königsberski, który wchodził w skład Rosyjskiej FSRR. Na mocy dekretu z 4 czerwca 1946 roku nazwa tego obwodu została zmieniona na Kaliningradzki ${ }^{3}$. Bezpośrednim asumptem do stworzenia przez ZSRR Obwodu Kaliningradzkiego były postanowienia konferencji poczdamskiej, kiedy to likwidacji uległy Prusy Wschodnie ${ }^{4}$. Region, o który tak bardzo zabiegał Józef Stalin $^{5}$, od początku otrzymał jasno sprecyzowane zadanie: kontrola wschodniej części Bałtyku, Zatoki Botnickiej oraz Zatoki Gdańskiej ${ }^{6}$. W krótkim czasie doszło do „prawie totalnego zmilitaryzowania tego obszaru" , co w połączeniu z zamknięciem granic dla przybyszów z zewnątrz oraz z wysiedleniem cywilnej ludności niemieckiej, na długie lata określiło charakter tego regionu w międzynarodowej rzeczywistości politycznej. Zarówno znaczenie geopolityczne jak i silne zmilitaryzowanie obszaru (przynajmniej do niedawna) nie pozostają bez wpływu na dzisiejszą sytuację Obwodu Kaliningradzkiego.

Rozpad ZSRR na nowo wyznaczył miejsce Obwodu Kaliningradzkiego na politycznej mapie Europy. Interesujący nas region, niejako po raz kolejny, rozpoczął swoją egzystencję, tym razem jako część Rosji odseparowana od całości terytoriami suwerennych państw. Taki rozwój sytuacji nie wpłynął ujemnie na znaczenie, jakie Kaliningrad posiada dla Rosji. Wręcz przeciwnie: położenie Obwodu Kaliningradzkiego zaczęło nabierać dla FR większego znaczenia, wraz z koniecznością wycofania jej wojsk z baz morskich wschodniego wybrzeża Morza Bałtyckiego - Kłajpedy, Pałangi, Rygi, Tallina ${ }^{8}$.

Niemal jednocześnie na terenie Obwodu Kaliningradzkiego powstała Wolna Strefa Ekonomiczna "Jantar". Wraz z nią pojawiły się nadzieje na znaczący rozwój gospodarczy oraz przyciągnięcie inwestycji kapitałowych,

S. Nis, Kaliningrad - nie jedinstwiennyj anklaw, „Pro et Contra”, tom 8, nr 1,2003, s. 98.

J. Dudo, Gospodarcze aspekty środowiska naturalnego w obwodzie kaliningradzkim, Olsztyn 1995, s. 5.

W. Modzelewski, Geneza i tożsamość Obwodu Kaliningradzkiego FR, w: Narody i nacjonalizm w Federacji Rosyjskiej, P. Timofiejuk, A. Wierzbicki, E. Zieliński (red.), Warszawa 2004, s. 193.

Teheran - Jałta - Poczdam. Dokumenty konferencji szefów rzadów trzech wielkich mocarstw, tłum. W. Daszkiewicz, A.D. Rotfeld, Warszawa 1972, s. 87; por. E. Wojnowski, Rola Obwodu Kaliningradzkiego w strategii geopolitycznej Federacji Rosyjskiej, w: Europa a Rosja - opinie, konflikty, wspótpraca: studia, Z. Anculewicz, J. Sobczak (red.), Olsztyn 2003, s. 135.

W. Modzelewski, dz. cyt., s. 194.

E. Wojnowski, dz. cyt., s. 135.

W. Kotowicz, Znaczenie Obwodu Kaliningradzkiego dla interesów narodowych Rosji, w: Narody i nacjonalizm w Federacji.., s. 209.

O. Szura, dz. cyt., s. 153. 
głównie członków EWG. Należy nadmienić, iż korzystna infrastruktura komunikacyjna Kaliningradu dawała szerokie perspektywy dla rozwoju. Tego rodzaju strefa mogłaby sugerować Zachodowi pozytywne nastawienie Rosji do rozwijania międzynarodowej współpracy gospodarczej ${ }^{10}$.

Wobec powyższego, warto zwrócić uwagę na relację pomiędzy Kaliningradem a Moskwą, które znacząco determinowały kaliningradzkie perspektywy oraz stanowiły dla państw UE (wcześniej: dla państw EWG) określony sygnał. Najbardziej wysunięty na Zachód obwód z pewnością, ze swej perspektywy, widział dla siebie trochę inne szanse rozwoju niż mogli to zauważyć politycy z Moskwy. W owym czasie część elit Obwodu Kaliningradzkiego opowiadała się za większą samodzielnością w decydowaniu o kierunkach postępu, zwłaszcza ekonomicznego, i planach ich realizacji ${ }^{11}$. Wpływ na zaistniałą sytuację miało zapewne zwiększenie możliwości bezpośredniego kontaktu z krajami zachodnimi. W ten sposób doszło do swoistego paradoksu. Obwód Kaliningradzki okazał się izolowany od reszty Federacji Rosyjskiej, z kolei łatwiej było o wyjazdy i nawiązywanie kontaktów z zagranicą ${ }^{12}$. Taka sytuacja w samym Obwodzie Kaliningradzkim była postrzegana jako szansa, choć w Moskwie ten stan rzeczy mógł być interpretowany negatywnie.

Powyższe fakty jednoznacznie wskazują na „różnice interesów” pomiędzy Moskwą a Kaliningradem. Moskwa, z jednej strony, chce widzieć w Obwodzie Kaliningradzkim rzecznika interesów całej Rosji, z drugiej strony, obawia się jednak dużego usamodzielnienia tego regionu. Taki stan rzeczy sprawiał, iż relacje Moskwa - Kaliningrad nie zawsze układały się najlepiej. Centrum niejednokrotnie nie miało pomysłu na wykorzystanie możliwości swej enklawy, z kolei enklawa irytowała się przeszkodami, jakie piętrzyła przed nimi stolica. Założenia WSE "Jantar" nie zostały zrealizowane w praktyce. Za deklaracjami nie pojawiły się żadne konkretne rozwiązania ze strony odpowiednich urzędów bądź ministerstw, które ożywiłyby kontakty gospodarcze albo przyciągnęły potencjalnych inwestorów z zagranicy ${ }^{13}$. Również walka o ustawowe uregulowanie statusu prawnego Obwodu Kaliningradzkiego, jaką podjęli miejscowi reformatorzy, wykazała podejście Moskwy do aspiracji Kaliningradu. Mimo zatwierdzenia w 1996 roku ustawy o szczególnej (specjalnej) strefie ekonomicznej w Obwodzie Kaliningradzkim, kwestia rozwoju tego regionu znów utknęła w martwym punkcie. Przyczyną tego był, podobnie jak w wypadku WSE "Jantar", brak przepisów wy-

\footnotetext{
E. Wojnowski, dz. cyt., s. 136.

Tamże, s. 137.

Przezwyciężanie obcości. Kaliningrad jako rosyjska enklawa wewnątrz Unii Europejskiej, oprac.

G. Gromadzki, A. Wilk, Warszawa 2001, s. 3.

13 O. Szura, dz. cyt, s. 153.
} 
konawczych, a także swobodna interpretacja poszczególnych zapisów ustawy, dokonywana przez władze federalne ${ }^{14}$. Nieco wcześniej podpisana została umowa o rozgraniczeniu kompetencji władz Federacji Rosyjskiej i władz Obwodu Kaliningradzkiego. Umowy tego typu zawierane były również z innymi podmiotami $\mathrm{FR}^{15}$. Można zaryzykować stwierdzenie, że władze FR, niejako wyczuwając prozachodnie zapatrywania pewnej części obywateli Obwodu Kaliningradzkiego, starały się celowo umniejszyć rolę oraz potencjał tego regionu. Z drugiej strony fiaska inicjatyw WSE „Jantar” oraz Specjalnej Strefy Ekonomicznej nie należy jednoznacznie utożsamiać z obawami centrum o losy swej enklawy. Brak konkretnego planu wobec swego regionu oraz eksperymentowanie z niektórymi rozwiązaniami wskazuje również na poszukiwanie przez Rosję recepty na relacje z Unią Europejską. Na tym etapie Moskwa poszukiwała obszaru, na którym można by zbierać i rozwijać doświadczenia w relacjach z Brukselą. Takim obszarem okazał się Kaliningrad. O tym, że był to okres eksperymentowania, a nie ściśle określonego planu świadczył ówczesny, nie zawsze przewidywalny, stosunek Kremla do Obwodu Kaliningradzkiego.

Duże znaczenie dla rozwoju „najbardziej zachodniego” obwodu FR mają układy personalne. Stosunek gubernatora do centrum oraz do kwestii ewentualnych inwestycji zagranicznych ma niebagatelny wpływ na rozwój Obwodu Kaliningradzkiego. Dlatego też lata rządów Leonida Gorbienki (1997 - 2000), negatywnie nastawionego do kontaktów z Zachodem, uważa się powszechnie za okres zaprzepaszczonej szansy ${ }^{16}$. Również stosunek prezydenta FR do analizowanej kwestii nie pozostaje bez znaczenia. O ile Borys Jelcyn jawił się jako symbol słabości centrum wobec peryferiów, o tyle Władimir Putin uosabiał dążenie do wzmocnienia centrum kosztem rozwijających się regionów ${ }^{17}$.

Zarówno brak jasno sprecyzowanego planu jak i układy personalne w sposób wyraźny wpłynęły na sytuację Obwodu Kaliningradzkiego. Jednak obawy przed dezintegracją Federacji Rosyjskiej jak również styl rządzenia rosyjskich polityków nie wyczerpywał listy zagadnień, z którymi musiała się

$4 \quad$ E. Wojnowski, dz. cyt., s. 138.

15 Tamże, s. 138. O przewidywanym wpływie tej umowy na relacje gospodarcze Obwodu Kaliningradzkiego z zagranicą (przykład Polski) zob: J. Zwieriew, Formirowanije infrastruktury SEZ „Jantar" kak faktor aktiwizacyi rossijsko-polskogo prigranicznego sotrudniczestwa, w: Problemy wspótpracy przygranicznej pomiędzy Polską i Obwodem Kaliningradzkim Federacji Rosyjskiej, A. Stasiak, T. Komornicki (red.), Warszawa 1994, s. 146-147.

16 T. Paszewski, A. Maciejewski, Kaliningrad $w$ perspektywie rozszerzenia UE, s. 7, dostępne: http://www.rcie.lodz.pl/info/dokumenty/05_opracowania/csm/CSM\%200202\%20kaliningrad.pdf [18.11.2008]; O. Szura, dz. cyt., s. 156.

17 Przezwyciężanie obcości..., s. 6. 
zmierzyć enklawa. Oprócz dzielenia losu przeciętnego regionu FR, który w latach 90 . skazany był na kryzys gospodarczy ${ }^{18}$, Kaliningrad okazał się także obiektem szczególnego zainteresowania w relacjach unijno-rosyjskich. Zainteresowanie to przypadło jednak na lata późniejsze, kiedy to Unia Europejska zaczęła przygotowywać się do poszerzenia swoich granic o 10 państw, spośród których znaczna część była połączona z FR wspólną, nie zawsze najszczęśliwszą, historią.

Wraz z rozpadem ZSRR i powstaniem WSE „Jantar" Obwód Kaliningradzki zaczął wzbudzać pewne zainteresowanie wśród państw Europy Zachodniej. Już w 1992 roku delegacja Rady Państw Bałtyckich wśród przesłanek dla rozwoju Kaliningradu wymieniła m.in. ścisłe powiązanie z EWG. W tym kontekście Obwód Kaliningradzki miał być rozwijany jako euroregion i torować drogę do EWG Rosji i państwom WNP ${ }^{19}$. Organy EWG, a niedługo potem Unii Europejskiej, badały możliwość związania Obwodu Kaliningradzkiego z całym obszarem Morza Bałtyckiego poprzez różne formy współpracy. W tym celu, 8 lutego 1994 roku, Parlament Europejski przyjął rezolucję „W sprawie Kaliningradu (Königsbergu) rosyjskiej enklawy nad Morzem Bałtyckim: sytuacja i perspektywy z europejskiego punktu widzenia", do którego dołączono oświadczenie wyjaśniające powody postulowanych rozwią$z_{a n}{ }^{20}$. Ten dość znaczny krok, poczyniony w kierunku rozwiązania lub przynajmniej zanalizowania najbardziej palących problemów dotyczących obwodu Kaliningradzkiego, nie został jednak pozytywnie oceniony przez stronę rosyjską. Federacja Rosyjska uznała ten dokument za próbę ingerencji w wewnętrzne sprawy niepodległego państwa. Efektem takiego rozwoju sytuacji okazało się pewne zdystansowanie UE dotyczące działań w sferze Kaliningradu. Rosja także dość sceptycznie odbierała następne unijne poczynania, jakby doszukując się w nich prób dezintegracji swego państwa. Kolejne lata, będące okresem rządów gubernatora negatywnie nastawionego do Zachodu - Leonida Gorbienki, okazały się niezbyt owocne dla podnoszenia kwestii kaliningradzkiej na forum europejskim.

Zmiana w rosyjsko-unijnych relacjach dotyczących Kaliningradu została zainicjowana przez Władimira Putina, który na posiedzeniu Rady Europy w lutym 1999 roku użył sformułowania o „pilotażowej roli” Obwodu Kaliningradzkiego ${ }^{21}$. Wydaje się, że w tym czasie, zarówno po stronie rosyjskiej jak i unijnej, zaczęła kształtować się świadomość nieuchronnych zmian w sytuacji międzynarodowej. Unia, zmierzająca do rozszerzenia swych struktur,

\footnotetext{
A. Stępień-Kuczyńska, dz. cyt., s. 213.

E. Wojnowski, dz. cyt., s. 136.

Szerzej zob.: Tamże, s. 140-142.

Tamże, s. 142.
} 
uświadomiła sobie niebagatelne znaczenie rosyjskiej enklawy dla spójnego rozwoju wszystkich (zarówno przyszłych jak i obecnych) swoich członków. Rosja przez niemal całe lata 90. postrzegała swoją politykę zagraniczną przez pryzmat relacji ze Stanami Zjednoczonymi i rywalizacji z USA o kształt ładu europejskiego. Stosunki z UE, mimo iż formalnie priorytetowe, okazały się mieć $\mathrm{w}$ rzeczywistości drugorzędną rangę ${ }^{22}$. Unia Europejska postrzegana była przez FR bardziej jako inicjatywa o charakterze ekonomicznym, niż politycznym. Wobec takiej interpretacji sytuacji nie dziwi fakt, iż przez długi czas dla europejskiego kierunku rosyjskiej polityki zagranicznej najważniejsze były kwestie dotyczące funkcjonowania NATO i KBWE/OBWE ${ }^{23}$. Wraz ze zmianą polityczną (prezydentura Putina) jaka dokonała się na Kremlu, doszło do realnego ocieplenia stosunków pomiędzy UE a Rosją. Wpływ na tę sytuację miały rozmaite czynniki, których źródeł nie należy szukać tylko w Europie $^{24}$. W efekcie pojawiła się nowa szansa na korzystne rozwiązanie „kaliningradzkiego problemu". Dodatkowym impulsem, jaki został wysłany przez UE w kierunku Federacji Rosyjskiej, było zainicjowanie programu „Wymiar Północny", którym objęty został także Obwód Kaliningradzki ${ }^{25}$. Inicjatywa ta, swoim zakresem obejmująca bardzo szerokie spektrum działalności (m.in. gospodarka, ekologia), wywołała pozytywny oddźwięk wśród polityków rosyjskich. Jednocześnie warto zauważyć, iż wymieniony projekt wpisywał się w szerszy sposób prowadzenia polityki przez Unię Europejską. Skupienie się na miękkich aspektach bezpieczeństwa oraz integracja w regionie stanowią w tym wypadku unijny sposób prowadzenia działań politycznych ${ }^{26}$.

Ważnym wydarzeniem w relacjach unijno-rosyjskich dotyczących Kaliningradu było opublikowanie w styczniu 2001 roku komunikatu Komisji Europejskiej „UE a Kaliningrad”, który otworzył nową fazę w dyskusji na temat przyszłości Obwodu Kaliningradzkiego ${ }^{27}$. Komunikat KE składał się z dwóch części: jedna z nich mówiła o korzyściach dla Kaliningradu wynikających z rozszerzenia Unii Europejskiej, druga z kolei wskazywała na wyzwania i zagrożenia, z którymi Kaliningrad zmuszony będzie się zmierzyć. Mimo iż debata na ten temat toczyła się już od dłuższego czasu, to jednak właśnie wspomniany raport pobudził wszystkie zainteresowane strony do uważniejszego przyjrzenia się problemowi. Oczywiście debata dotycząca

\footnotetext{
M. Kaczmarski, Rosja na rozdrożu, Warszawa 2006, s. 73.

A. Bryc, Cele polityki zagranicznej Federacji Rosyjskiej, Toruń 2004, s. 65-66.

Zob. R. Zięba, Wspólna Polityka Zagraniczna i Bezpieczeństwa Unii Europejskiej, Warszawa 2007, s. 161.

T. Paszewski, A. Maciejewski, dz. cyt., s. 2-3.

A. Bryc, Rosja w XXI wieku. Gracz światowy czy koniec gry?, Warszawa 2008, s. 112.

T. Paszewski, A. Maciejewski, dz. cyt., s. 3
} 
przyszłości „najbardziej zachodniego” regionu Rosji toczyła się w ramach rozmów o przyszłych stosunkach unijno-rosyjskich, które po planowanym rozszerzeniu UE musiały ulec modyfikacji.

Wśród problemów, jakie podnosiła Rosja w kontekście planowanego rozszerzenia UE, ważne miejsce zajmowała kwestia ewentualnych utrudnień w przekraczaniu granic nowych członków UE oraz sprawa tranzytu z Federacji Rosyjskiej do Kaliningradu ${ }^{28}$. Komisja Europejska, dostrzegając powstały problem, jasno określiła, iż Kaliningrad nie może liczyć na specjalne traktowanie ze strony UE. Zanegowana została również możliwość bezwizowego ruchu na granicy przyszłych członków UE z Rosją po przyjęciu ich do układu z Schengen. Federacja Rosyjska nie zaakceptowała stanowiska Unii, jakie zostało przedstawione w raporcie Komisji Europejskiej. Dla Rosji szczególnie ważna była sprawa tranzytu - z i do Kaliningradu, wobec tego nie zamierzała rezygnować z możliwości wywalczenia dla siebie korzystnych rozwiązań. Licząc na ustępstwa Unii Europejskiej, w marcu 2001 roku rosyjski MID ${ }^{29}$ przedstawił swoje warunki. Szczególne znaczenie - z punktu widzenia polskiej i litewskiej polityki zagranicznej - miała propozycja wydzielenia eksterytorialnych korytarzy z Kaliningradu przez Polskę, Litwę i Białoruś do Rosji. Propozycja ta została w sposób zdecydowany odrzucona przez stronę unijną. Federacja Rosyjska wykazała się jednak nieustępliwością i w marcu 2002 roku przedłożony został projekt bezwizowej linii kolejowej pomiędzy Federacja Rosyjską a Kaliningradem ${ }^{30}$. Również ta propozycja, wobec zdecydowanego sprzeciwu Polski i Litwy, została odrzucona przez Unię Europejską. Federacja Rosyjska próbując wywalczyć dla siebie korzystne rozwiązania w kwestii wiz i tranzytu, liczyła zapewne na przejściową słabość Unii Europejskiej spowodowaną np. zmianami wynikającymi z rozszerzenia. Taka sytuacja mogła przecież osłabić wewnętrzną spójność. Warty zauważenia jest również fakt, iż po okresie ożywionych relacji z Unią Europejską (2000-2001) kierunek europejski ponownie stracił dla Rosji na znaczeniu. Powodem takiego stanu rzeczy był rozwój sytuacji politycznej na świecie po 11 września 2001 roku. W efekcie doszło do amerykańsko-rosyjskiego zbliżenia, które dla Unii Europejskiej oznaczało okres stagnacji w relacjach z Rosją. Federacja Rosyjska, rezygnując z roli światowego mocarstwa, postawiła jednocześnie na wzmocnienie swojej pozycji jako regionalnego mocarstwa euroazjatyckiego ${ }^{31}$. Taki

S. Afoncew, Rossija i ,nowyj ES”, „Pro et Contra”, tom 8, nr 1,2003, s. 36.

MID - rosyjski MSZ (Ministierstwo Inostrannych Dieł)

A. Bryc, Rosja w XXI wieku..., s. 112.

M. Kaczmarski, Polityka Rosji wobec Unii Europejskiej, s. 7, dostępne: http://www.csm.org.pl/ images/rte/File/Raporty\%20i\%20publikacje/Raporty\%20i\%20analizy/2005/rap_i_an_0805. pdf [18.11.2008] 
rozwój sytuacji mógł skłonić FR do zajęcia dość zdecydowanego stanowiska w kwestii wiz i tranzytu z UE. Nie ulega wątpliwości, że gra o Kaliningrad była dla Rosji czymś więcej niż tylko próbą korzystnego rozwiązania kwestii przejazdów z i do Kaliningradu. Uprawnione wydaje się również stwierdzenie, iż była to także próba wywalczenia sobie przez Federację Rosyjską uprzywilejowanej pozycji (względem innych państw) w relacjach z Unią Europejską ${ }^{32}$. Moskwa liczyła w ten sposób na ustanowienie precedensu, który mógłby określić nową formułę stosunków unijno-rosyjskich na najbliższe lata. Obwód Kaliningradzki stał się w tym wypadku elementem gry politycznej. Rosja wykorzystała swój „najbardziej zachodni” region do przetestowania pewnego wariantu rozwoju sytuacji. O tym, iż był to wariant nieudany świadczą ostateczne ustalenia dotyczące kwestii wiz i tranzytu. Zarówno Polska jak i kraje bałtyckie dostosowały się do wymogów systemu Schengen i wprowadziły wizy dla obywateli rosyjskich. Rozwiązanie kwestii tranzytu zostało natomiast odłożone w czasie.

Osobnym problemem, z jakim zmierzyć musiał się Obwód Kaliningradzki, była sprawa dużej liczby wojsk stacjonujących na tym terenie. W okresie po II wojnie światowej region ten, jednocześnie stając się częścią ZSRR, został silnie zmilitaryzowany. Wraz z rozpadem ZSRR i zmianami politycznymi na świecie Obwód Kaliningradzki nabrał dla Rosji większego znaczenia strategicznego, czego przyczyną była wspomniana już niemożność korzystania z innych baz morskich, które weszły w skład niepodległych państw. Dodatkowo, znaczenie militarne Obwodu Kaliningradzkiego wzmocnione jest poprzez fakt obecności na tym terenie niezamarzających portów będących do dyspozycji Rosji ${ }^{33}$. Władze rosyjskie powołując się na proatlantyckie dążenia państw nadbałtyckich i Polski, uzasadniały konieczność utrzymania militarnego statusu „najbardziej zachodniego” ze swych regionów. Tym niemniej, w drugiej połowie lat dziewięćdziesiątych doszło do przeorganizowania wojsk stacjonujących na terenie Obwodu Kaliningradzkiego. Redukcji uległa liczba wojsk stacjonujących na tym terenie, jednak ilość została zamieniona na jakość. Flota Bałtycka (w jej skład wchodzą wszystkie jednostki z terenu Obwodu) jest „prawdopodobnie jedyną tego szczebla strukturą Sił Zbrojnych FR, która dopasowała się do nowej sytuacji geopolitycznej i ekonomicznej Rosji ${ }^{34 "}$. Jednocześnie, pod rządami Władimira Putina zrezygnowano $\mathrm{z}$ forsowania polityki tzw. twierdzy kaliningradz$k_{i e j}{ }^{35}$. Powyższe fakty mogą świadczyć o zmniejszeniu zagrożenia jakie we-

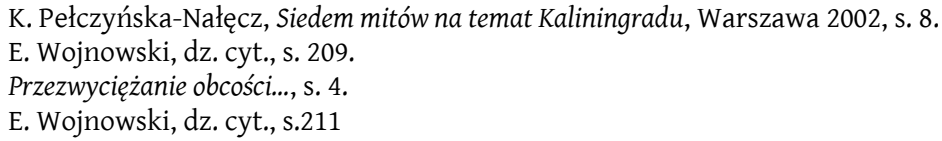


wnątrz Unii Europejskiej mogłaby wywołać silnie zmilitaryzowana rosyjska „wyspa”. Wraz z rozpoczęciem działań w kierunku bardziej ożywionej współpracy problem ten praktycznie przestał być podnoszony. Można zaryzykować stwierdzenie, że kwestia liczebności wojsk rosyjskich na terenie Obwodu Kaliningradzkiego wydaje się adekwatna i nie budzi niczyich zastrzeżeń. Problemem, z europejskiego punktu widzenia, jest samo położenie Kaliningradu. W razie pogorszenia się relacji sytuacja militarna w tym regionie może się znacząco zmienić. W takim wypadku, pogląd, iż Kaliningrad jest barometrem zmian relacji unijno-rosyjskich, okaże się jak najbardziej zasadne.

Osobną kwestię stanowi ewentualna obecność na terenie Obwodu ładunków nuklearnych ${ }^{36}$. Wydaje się, że potwierdzenie przez Rosję takich informacji zdecydowanie ochłodziłoby jej relacje z Europą. Jednak gra taką kartą musiałaby być spowodowana znaczącymi zmianami w światowej polityce i Rosja świadoma byłaby stawki takiej gry.

Dla mieszkańców Obwodu Kaliningradzkiego militarny, przynajmniej jeszcze do niedawna, charakter regionu nie stanowi większego problemu. Wręcz przeciwnie, znaczenie ekonomiczne Floty Bałtyckiej, która zapewnia stabilne miejsca pracy i duży potencjał nabywczy, wydaje się korzystnie wpływać na tamtejszą gospodarkę ${ }^{37}$.

Wraz z „wschodnim” rozszerzeniem Unii Europejskiej sytuacja polityczna Obwodu Kaliningradzkiego uległa zmianie. Powstaje pytanie o bilans tego rozszerzenia z punktu widzenia rosyjskiej enklawy.

Wspomniany dokument „UE a Kaliningrad” wymienia cztery dziedziny, które ulegną zmianie w Obwodzie Kaliningradzkim po rozszerzeniu z 2004 roku. Handel zagraniczny, ruch osobowy, zaopatrzenie Obwodu w energię elektryczną oraz rybołówstwo stanowić miały obszary, w których zmiany będą szczególnie widoczne ${ }^{38}$. Unia uznała, że w przypadku wszystkich wymienionych dziedzin, poza sprawą ruchu osobowego, inicjatywa co do zmian należy do Federacji Rosyjskiej. Oczywiście Obwód Kaliningradzki może liczyć na pomoc Unii, ale pod warunkiem, iż nie będzie tylko biernym biorcą, a okaże się również gospodarzem, któremu zależy na korzystnych przeobrażeniach.

Sprawa handlu zagranicznego przedstawiana jest jako szansa na rozwój Obwodu Kaliningradzkiego. Wraz z wstąpieniem Polski i Litwy do Unii obniżeniu uległy taryfy celne na towary przemysłowe sprowadzane z Kali-

Zob. Przezwyciężanie obcości..., s. 5.

Tamże, s. 5.

T. Paszewski, A. Maciejewski, dz. cyt., s. 4. 
ningradu. Taka sytuacja może mieć pozytywny wpływ na rozwój handlu, o ile towary z Obwodu Kaliningradzkiego sprostają wysokim standardom unijnym ${ }^{39}$.

Dodatkowym impulsem do rozwoju Kaliningradu ma być również ustawa o Szczególnej Strefie Ekonomicznej w Obwodzie Kaliningradzkim, która weszła w życie 1 kwietnia 2006 roku. Podstawowym założenie nowych ustaleń zawartych w ustawie jest uprzywilejowana pozycja przedsiębiorców - rezydentów regionu, od których w ciągu pierwszych sześciu lat nie będzie pobierany podatek dochodowy, uzyskany w ramach realizowanego przez nich projektu ${ }^{40}$. Takie ustalenia mogą wpłynąć pozytywnie na wzrost zainteresowania inwestorów, także zagranicznych, „najbardziej zachodnim” z regionów Rosji. Choć z drugiej strony, nie brak głosów, iż ustawa o SSE sprzyja silnym gospodarczo strukturom moskiewskim i nie w pełni otwiera rynek kaliningradzki na inwestorów z zagranicy ${ }^{41}$. 0 rzeczywistych skutkach tej inicjatywy będzie można przekonać się po upływie dłuższego okresu, kiedy to widoczne staną się efekty wspomnianej powyżej ustawy. Warto podkreślić, iż wraz z wejściem w życie ustawy o SSE uproszczeniu uległy zasady wjazdu obcokrajowców na teren obwodu. Takie postępowanie może być odbierane jako kolejny krok w rozwoju pozytywnych relacji unijno-rosyjskich.

Sprawa ruchu osobowego i tranzytu, która jeszcze przed rozszerzeniem budziła spore kontrowersje i stała się elementem gry politycznej, podlega stopniowym zmianom. Federacja Rosyjska negocjowała z Unią Europejska listę ulgowych kategorii swoich obywateli, dla których wprowadzony zostanie uproszczony tryb wjazdu do krajów Unii ${ }^{42}$. Celem Rosji jest w tym wypadku doprowadzenie do całkowitego ruchu bezwizowego pomiędzy Obwodem Kaliningradzkim a krajami Unii Europejskiej. Wykonanie takiego zadania możliwe będzie w pewnej perspektywie czasu, zakładając, że stosunki rosyjsko-unijne nie ulegna gwałtownemu pogorszeniu. Obecnie, wizja ruchu bezwizowego pomiędzy krajami Unii a Rosją stanowi odległą przyszłość. Problem tranzytu z i do Kaliningradu nadal nie jest do końca rozwiązany i podobnie jak w przypadku ruchu osobowego, podlega zmianom. W tym

39 Tamże, s. 4.

40 „Obwód Kaliningradzki. Przegląd faktów, wydarzeń, opinii”. Biuletyn Towarzystwa Naukowego i Ośrodka Badań Naukowych im. Wojciech Kętrzyńskiego w Olsztynie, dalej: „Obwód Kaliningradzki”, nr 1, 2006, s. 51.

41 Tamże, s. 2.

42 „Regiony i Pogranicza: Kaliningrad: fakty, wydarzenia, opinie”. Periodyk Towarzystwa Naukowego i Ośrodka Badań Naukowych im. Wojciecha Kętrzyńskigo w Olsztynie, nr 10, 2007, s. 2. 
wypadku, rozmowy prowadzone są jednak bezpośrednio między zainteresowanymi krajami (Rosja i Litwa) ${ }^{43}$.

Unia Europejska, poprzez szereg rozmaitych działań podejmowanych na różnych poziomach, nieustannie dąży do wciągnięcia Obwodu Kaliningradzkiego w system gospodarczy regionów Morza Bałtyckiego. Kaliningrad uczestniczy w pracy euroregionów „Bałtyk”, „Saule”, „Niemen”, „Szeszupa” i „Łyna - Ława”. Realizowane są projekty w zakresie współpracy przygranicznej ${ }^{44}$. Dodatkowo, wraz z „europeizacją” problemu Obwodu Kaliningradzkiego wzrasta zainteresowanie unijnych inwestorów. Nie ulega wątpliwości, iż współpraca krajów Unii Europejskiej z Kaliningradem stanowi swoisty poligon doświadczalny, wewnątrz którego wypracowywane są pomysły na rozwój współpracy na szerszą skalę. Zdobywanie takiego doświadczenia wydaje się być korzystne dla obu stron.

Obwód Kaliningradzki zajmuje w relacjach pomiędzy Unią Europejską a Federacją Rosyjską szczególne miejsce. Ta „szczególność” wynika z kilku przyczyn. Niewątpliwie najważniejszą z nich jest usytuowanie geograficzne, które zarówno Unii jak i Rosji nastręcza niemało kłopotów.

Ze strony państw wchodzących w skład Unii nie milkną głosy o „czarnej dziurze" w zjednoczonej Europie, która może być nieprzewidywalna w swoich działaniach. Dlatego też należy ucywilizować zaistniały problem, gdyż dyskomfort zagrożenia z wewnątrz jest niełatwy zniesienia. Problem skażenia ekologicznego, o jakie oskarżany jest Obwód Kaliningradzki, mówi sam za siebie. Obecność regionu rosyjskiego wewnątrz intensywnych działań integracyjnych daje Federacji Rosyjskiej pretekst do zainteresowania się konkretnymi działaniami Unii Europejskiej i zajęcia, przynajmniej w niektórych kwestiach, określonego stanowiska. Oficjalnym powodem takich poczynań jest troska o dobro obywateli Obwodu Kaliningradzkiego i obawa przed dezintegracją państwa rosyjskiego. Stanowisko FR można uznać za zasadne, jednak stwarza ono duże możliwości do stosowania różnorodnych nacisków na kraje Unii Europejskiej. Rosja, w niektórych sytuacjach, skwapliwie korzysta $\mathrm{z}$ tych możliwości, w pełni wykorzystując swoja pozycje międzynarodową.

Federacja Rosyjska nieustannie podkreśla strategiczne znaczenie Obwodu Kaliningradzkiego. Jednocześnie, w pełni zdaje sobie sprawę z zagrożeń, jakie niesie za sobą funkcjonowanie odizolowanego od centrum terytorium wewnątrz integrujących się krajów Europy. Dlatego też, wszelkie informacje o autonomicznych zapędach Kaliningradu są traktowane przez Mo-

Tamże, s. 3.

„Obwód Kaliningradzki”, nr 5, 2006, s. 39. 
skwę szalenie poważnie. Podobnie przyjmowane są wszelkie - zbyt daleko idące - propozycje Unii dotyczące „najbardziej zachodniego” z regionów Rosji.

Paradoksalnie, obszar, który nastręcza tak wielu kłopotów, staje się również szansą na rozwijanie unijno-rosyjskich relacji. Wydaje się, że w tym wypadku Unia i Rosja są na siebie skazane. Ich interesy skupione wokół Obwodu Kaliningradzkiego często się krzyżują czy wręcz wykluczają. Jednak nie brak również wspólnych przedsięwzięć i planów. I właśnie na bazie powstających punktów stycznych, które o wiele częściej oznaczają wspólnotę interesów niż wartości, należy budować porozumienie.

Obwód Kaliningradzki jeszcze przez długi czas będzie pełnił rolę niezwykle czułego barometru zmian na linii Bruksela - Moskwa. Uważne obserwowanie tego regionu pozwoli na wywnioskowanie nastrojów i priorytetów w polityce Rosji i Unii. Jednocześnie Kaliningrad pozostanie miejscem przeprowadzania doświadczeń i działań o różnym charakterze, które obu stronom dadzą pewne wiadomości o stanie ich stosunków z drugim podmiotem.

Jakie stanowisko wobec przypisanej mu roli zajmie sam Kaliningrad? Pod rządami prezydenta Miedwiediewa i gubernatora obwodu Boosa jego sytuacja zapewne nie ulegnie znaczącym zmianom, o ile zmianom nie będzie podlegać sama sytuacja międzynarodowa i stosunki UE - Rosja. Mieszkańcy Kaliningradu, coraz bardziej świadomi swej odrębnościci ${ }^{45}$, będą starali się jak najlepiej spożytkować swą wyjątkową pozycję. W tym kontekście, jak najbardziej uzasadnione wydają się poglądy o stopniowym dryfowaniu tego regionu na Zachód ${ }^{46}$, którego podstawą mogą być relacje gospodarcze. Trudno określić, na ile posłuszeństwo wobec wytycznych z Kremla będzie w stanie zmienić przewidywany rozwój sytuacji.

Obwód Kaliningradzki stał się miejscem zbliżenia, częściowo mimowolnego, Rosji i Unii Europejskiej. Jednak nie ma wątpliwości co do pragmatycznego wymiaru takiego stanu. 0 trwałości tego zbliżenia zadecyduje rozwój sytuacji na scenie międzynarodowej. Kaliningrad, i w tym wypadku, będzie spełniał powierzoną mu rolę barometru zmian w stosunkach pomiędzy Federacją Rosyjską a Unią Europejską.

Zob.: W. Modzelewski, dz. cyt., s. 198-200.

46 A. Bryc, Rosja w XXI wieku..., s. 112. 


\section{Abstract}

In May 2004, simultaneously with the enlargement of the European Union, certain changes in political relations in Europe took place. Great majority of ten new states joining the European Union either composed or was under the influence of the Soviet Union. This situation changed bilateral relations between the European Union and the Russian Federation as well as those between Russia and ten new members. In this context, both the Russian Federation and the European Union focused on Kaliningrad Oblast which, simultaneously with the enlargement of the European Union, became Russian enclave inside the European Union.

The neighborhood of Kaliningrad constitutes a chance for the European Union to develop economical and political cooperation with Russia and improve bilateral relations. On the other hand, a part of Russian territory inside the European Union could serve as a pretext to exert pressure on some European issues. Kaliningrad Oblast is a challenge for the European Union, being obliged to manage with a part of Russian jurisdiction inside the territory of strong unification. The Russian Federation emphasizes the strategic importance of Kaliningrad Oblast, but is also aware of the dangers of its isolation. Recent past is marked by political differences between Russian government and local authorities in Kaliningrad. Moreover, Kremlin presents different attitudes concerning Kaliningrad Oblast. As a result, the role of Kaliningrad Oblast in bilateral relations between the European Union and Russia is very specific. Both the Russian Federation and the European Union attempt to implement various solutions on this territory. In this case Kaliningrad Oblast plays a special role. Russian and European approach to Kaliningrad Oblast reflects the relations between Russia and the European Union. A moment of great importance was the year 2004, when the European Union was enlarged. In this context the situation of Kaliningrad Oblast changed. The future perspectives of this territory are also analysed in the article. 